\title{
ALBANIAN UNIVERSITY STUDENTS' ETHNIC DISTANCE AND STEREOTYPES COMPARED WITH OTHER BALKAN NATIONS
}

\author{
Edmond Rapti, Theodhori Karaj \\ University of Tirana, Albania \\ E-mail: edi_rapti@yahoo.com,dhorikaraj@yahoo.com
}

\begin{abstract}
The purpose of this study is to identify the Albanian university students' ethnic distance and the negative ethnic stereotypes compared with other ethnic groups in the Balkans. In addition, the study aims at determining the relationship between the ethnic distance and negative ethnic stereotypes. The sample of this study consists of 600 students selected at random in seven Albanian public universities. The instruments used in this study are a seven item ethnic distance scale for measuring the ethnic distance and a ten item scale for measuring ethnic stereotypes. The ethnic distance scale reliability coefficient is 0.76. The reliability coefficient for the ethnic stereotypes scale varies from 0.84 to 0.90 . The descriptive statistics (mean - comparison) is used to describe the level of ethnic distance and ethnic stereotypes. Pearson Product-moment Correlations are used to identify the intensity and orientation of the relation between the ethnic distance and stereotyped attitudes. The study findings indicate that Albanian university students manifest high levels of ethnic stereotypes and ethnic distance compared with other Balkan ethnic groups, especially Serbs and Greeks. In line with the other research, the findings of the present study indicate that there is a positive relationship between the ethnic distance and negative ethnic stereotypes. Key words: Balkan ethnic groups, ethnic distance, ethnic stereotypes.
\end{abstract}

\section{Introduction}

The Balkan countries have a long history of antagonistic fragmentation and diversity (Todorova, 1997). Its political history, beginning with the efforts for emergence and consolidation of their nations is full of conflicts and fights for national emancipation, creation and strengthening of its own national states, observation of ethnic minorities' rights, surmounting of ethnic conflicts (Burdiak, 2010). More than a decade has already passed since the ethnic armed conflicts of the 90s' between Serbians and Croatians, Bosnians and Albanians of Kosovo, Macedonians and Albanians of Macedonia in 2001, but the situation still remains tense, especially amongst Albanians of Kosovo and Serbs, Albanians of Macedonia and Macedonians. Apart from structural, political and economic factors that stir up ethnic conflicts, the cultural (perceptual) factor is considered the most crucial. (Brown, Cote, Lyn-Jones \& Miller, 1997). Ethnic stereotypes seem to essentially affect the urge for ethnic conflicts, especially in the initial latent phase. Stereotypes are generalized beliefs on certain social group members (Lippmann, 1922). They are collective beliefs of one social group towards another (Tajfel, 1981). Stereotypes are attributed to members of a social group only because of the fact that they belong to that particular group (Weber \& Crocker, 1983). Stereotypes are both positive and negative. According to Allport (1958), stereotypes are the very first step towards prejudices. While most of them are often interconnected with ethnic prejudices, stereotypes remain intact and much deeper rooted. Prejudices are attitudes that people have towards members of certain groups. 
PROBLEMS

OF EDUCATION

IN THE $21^{\text {st }}$ CENTURY

Volume 48, 2012

128

Stereotypes lead to propelling of racial prejudices, emotional reactions towards members of other ethnic groups (Katz \& Braly, 1935).

Ethnic stereotypes and prejudices lead to social distances: a situation where people experience feeling reactions towards one another (Bogardus, 1947). Ethnic distance is a kind of social distance amongst different ethnic groups. It derives from long-term acting ethnic stereotypes and prejudices. Ethnic distance allows for the expression of negative attitudes towards nations or ethnic groups. According to Allport (1958) the establishment of ethnic distance is the second phase in mounting prejudices against other nations and ethnic groups. Besides some cognitive functions much needed in simplifying the social reality and reducing effortful thought processes (Devine, 1989; Gilbert and Hixon, 1989), stereotypes exert some very important social functions. They simplify and justify actions taken by a group towards another ethnic group (Tajfel, 1981b; Allport, 1958). They legitimize the active presence of certain ideological systems (Jost and Banaji, 1994) by justifying and rationalizing on inequality (Glick and Fiske, 2001; Sidanius and Pratto, 1999).

Ethnic stereotypes in the Balkans are rooted in its past and present history. Burdiak (2010) notifies that ethnic stereotypes in the Balkans have sprung during the phase of the establishment of nations and respective national countries, a process that started during the Ottoman invasion and Austro-Hungarian war. After the empires' collapse, post war countries were faced by state building challenges. Territorial expansion that led them to wars with each other was a survival strategy. Lack of contacts led to nations' isolation in the Balkans. Ethnic minority groups were easily identified with the enemies. Arising stereotypes were reflected in their collective mind (Burdiak, 2010). This led to the birth of ethnic stereotypes.

Burdiak, (2010) research on reciprocity of negative stereotypes between Bulgarians and Turks, Bulgarians and Serbs, Serbs and Albanians, Serbs and Croatians, Greeks and Turks, Greeks and Bulgarians, Greeks and Albanians proves the mutual engagement of ethnicities in developing stereotypes. Neofotistos, (2004) confirms the presence of mutual negative ethnic stereotypes between Macedonians and Albanians of Macedonia.

Many empirical studies have proven the dynamic presence of ethnic distance between Serbs and other ethnic nations in ex-Yugoslavia. It appeared quite insignificant during 1960-1980, but grew larger in the late 80s' and 90s' and peaked highest in 2000 (Opačić \& Vujadinović, 2005). The ethnic social distance between Serbs and other ethnicities became more evident in the years to come, when the Yugoslav Republic collapsed and the era of the creation of new independent states through armed conflicts began. More recent studies prove the abundance of reciprocal negative stereotypes and social distance amongst Serbs, Croatians, Bosnians and Albanians of Kosovo (Opačić \& Vujadinović, 2005; Šiber, 1997). Research and surveys prove the presence of greater negative stereotypes and social distance towards other ethnic groups among Serbs, the greatest of all being that towards Albanians (Biro, Mihic, Milin \& Logar, 2002; Vujadinovic, Djukanovic \& Petkvovic, 2003; Opačić \& Vujadinović, 2005). Neofotistos, (2004) shows the presence of negative ethnic stereotypes between Macedonians and Albanians of Macedonia. Zheleznova (2003), Vidali (1999), Kokkali (2007), prove the presence of a variety of negative ethnic stereotypes amongst Greeks towards Albanian minority and immigrants living in Greece.

The presence of ethnic stereotypes and social distance is amply proved in recent research on young age groups as well. Studies prove the existence of a great ethnic distance amongst the young Serbs, Croatians, Bosnians and Albanians. Young Serbs keep greater ethnic distance towards the young people of other nationalities, especially those of ex-Yugoslavian background, the greatest of all being that against Albanian youth of Kosovo (Kandido-Jakšić, 1999; Biro, Mihic, Milin \& Logar, 2002). As it was shown in a research in 2007, the willingness of a young Serb in high school to marry an Albanian girl was 5 times lower than the willingness to marry Slovenian, Croatian and Macedonian girls (Kandido-Jakšić, 2008). Some other studies prove 
Edmond RAPTI, Theodhori KARAJ. Albanian University Students' Ethnic Distance and Stereotypes Compared With Other Balkan Nations

PROBLEMS

OF EDUCATION

IN THE $21^{\text {st }}$ CENTURY

Volume 48,2012

the existence of a greater ethnic distance between young Macedonian students and Albanian ones as compared to other ethnicities (Maleska, 2010; Beska, Majcevska, Kenig, Ballazhi, and 129 Tomovska, 2009; Joveska).

To the best knowledge of the authors, in Albania, there is not any other empirical study on the presence of ethnic stereotypes and social distances towards other ethnic groups in the Balkans. The main purpose of this study is to identify ethnic stereotypes and social distance of university students towards the others in the Balkans.

\section{Methodology of Research}

\section{General Background}

The present study is a non experimental quantitative one. It uses descriptive and correlational statistics to describe the variables and the orientation and strength of the relationship between them as well.

\section{Sample of Research}

The target population of this study are 50.000 bachelor students in Albanian public universities. A sample of 600 students were selected at random from this population in 6 Albanian public universities to approximately ensure $a \pm 3$ sampling error (Yamane, 1967). The sample is comprised of $73 \%$ female students and $27 \%$ male students.

\section{Instruments and Procedures}

The instrument used in this study was a structured questionnaire composed of three parts. The first part included questions related to demographic characteristics (gender, age, years of study, place of living). The second part was the seven items Bogardus scale of ethnic distance (1947) used to measure the ethnic distance. The questions aimed at gathering students' opinions on the relationship they would like to have with foreigners: (1) marriage (2) close friendship (3) neighbour (4) colleague at work (5) of the same citizenship (6) visitors in my country (7) not to allow them enter my country. The final version of the scale in the Albanian language was obtained based on the back translation procedure and was piloted with 100 university students who are not included in the study sample. The Cronbach's Alfa coefficient was used to estimate the instruments' internal consistency (Cronbach, 1951). The reliability coefficient for the ethnic distance scale was 0.76 . The third part of the questionnaire is a bipolar scale based on 10 negative and positive qualities for measuring stereotyped attitudes towards different ethnic groups. A fragment of this scale is as follows: 
PROBLEMS

OF EDUCATION

IN THE $21^{\text {st }}$ CENTURY

Volume 48,2012

According to your opinion, to what extent are the following characteristics typical of Greeks? Please think of Greeks as a group)

\begin{tabular}{|c|c|c|c|c|c|c|c|c|}
\hline Good & 1 & 2 & 3 & 4 & 5 & 6 & 7 & Bad \\
\hline Polite & 1 & 2 & 3 & 4 & 5 & 6 & 7 & Impolite \\
\hline Friendly & 1 & 2 & 3 & 4 & 5 & 6 & 7 & Unfriendly \\
\hline Calm & 1 & 2 & 3 & 4 & 5 & 6 & 7 & Quick -tempered \\
\hline Intelligent & 1 & 2 & 3 & 4 & 5 & 6 & 7 & Unintelligent \\
\hline Loyal & 1 & 2 & 3 & 4 & 5 & 6 & 7 & Disloyal \\
\hline Fair & 1 & 2 & 3 & 4 & 5 & 6 & 7 & Unfair \\
\hline Brave & 1 & 2 & 3 & 4 & 5 & 6 & 7 & Coward \\
\hline Hardworking & 1 & 2 & 3 & 4 & 5 & 6 & 7 & Lazy \\
\hline Civilized & 1 & 2 & 3 & 4 & 5 & 6 & 7 & Uncivilized \\
\hline
\end{tabular}

For each of the characteristics, the highest possible positive score was 1 and the lowest negative score was 7. Students were asked to describe characteristics of eight ethnic groups (selected nations). The data indicated the presence of stereotypes and ethnic distances of Albanian students towards different ethnic groups. The reliability coefficient varied from 0.84 to 0.90 .

\section{Data Collection}

The questionnaire was handed out to students in their workplace. Data gathering was administered during the academic year 2011-2012. Students responded to the questionnaire in their classes in the presence of the interviewers. 600 students completed the questionnaire and the overall response rate was $92 \%$.

\section{Data Analysis}

Data was analyzed in the statistical Program for Social Sciences (SPSS). The descriptive statistics (mean - comparison) was used to describe the level of the ethnic distance and stereotyped attitudes. Pearson Product-moment Correlations were used to identify the intensity and the orientation of the relation between the ethnic distance and stereotyped attitudes.

\section{Results of Research}

Table 1 shows the means and the standard deviation of the ethnic distance of Albanian students towards certain ethnic groups. The means are calculated based on the summing of seven items result. The results are ranked from 1 (the level of the closest ethnic distance) to 7 (the greatest ethnic distance). The mean results closer to value 1, it reveals a smaller ethnic distance. Closer to value 7 the mean, the greater the ethnic distance is. The data in table 1 indicates that Albanian students show a greater ethnic distance towards the Serbs $(\mathrm{M}=6.19)$ and Greeks $(M=5.71)$. Meanwhile, the ethnic distance towards some other ethnic groups is more moderate. 
Table 1. Ethnic distance of Albanian students towards some nations (mean ac-

PROBLEMS

OF EDUCATION

IN THE $21^{\text {st }}$ CENTURY

Volume 48, 2012 ceptance).

\begin{tabular}{|c|c|c|c|c|}
\hline & Minimum & Maximum & Mean & Std. Deviation \\
\hline Serbs & 1.00 & 7.00 & 6.19 & 1.32 \\
\hline Greeks & 1.00 & 7.00 & 5.71 & 1.62 \\
\hline Slovenians & 1.00 & 7.00 & 4.95 & 1.45 \\
\hline Bosnians & 1.00 & 7.00 & 4.84 & 1.56 \\
\hline Macedonians & 1.00 & 7.00 & 4.63 & 1.62 \\
\hline Croatians & 1.00 & 7.00 & 4.63 & 1.63 \\
\hline Montenegro & 1.00 & 7.00 & 4.58 & 1.62 \\
\hline
\end{tabular}

In table 2 are shown the data for each of the items in the ethnic distance scale composition. The students reveal a low preference for having intimate relationships with members of Balkan nations, mainly with Serbs. Only $1.3 \%$ would like to begin such a relationship with Serbs. Coherently, with such an attitude the interviewed students do not prefer to allow Serbs to approach their country. The same trend is also noted for the Greeks though a bit milder. (Over one third of the students would not like Greeks to come to their country).

Table 2. Ethnic distance towards some ethnic groups (in \%).

\begin{tabular}{|c|c|c|c|c|c|c|}
\hline & Macedonians & Montenegrin & Serbs & Croatians & $\begin{array}{c}\text { Sloveni- } \\
\text { ans }\end{array}$ & Bosnians \\
\hline Marriage Relations & 2.0 & 3.2 & 1.3 & 3.5 & 1.6 & 2.9 \\
\hline Close Friendship & 13.1 & 11.1 & 3.5 & 11.3 & 7.1 & 7.9 \\
\hline $\begin{array}{c}\text { Neighbours close to } \\
\text { my house }\end{array}$ & 13.3 & 14.0 & 2.0 & 13.1 & 10.9 & 11.8 \\
\hline Colleagues & 11.3 & 15.9 & 3.5 & 13.4 & 13.6 & 14.9 \\
\hline $\begin{array}{c}\text { Citizens (same citizen- } \\
\text { ship as me) }\end{array}$ & 18.1 & 12.7 & 2.0 & 10.3 & 10.6 & 9.4 \\
\hline $\begin{array}{c}\text { Visitors in my country } \\
\text { Should not be allowed } \\
\text { in my country }\end{array}$ & 36.5 & 38.1 & 32.2 & 45.8 & 53.7 & 48.2 \\
\hline
\end{tabular}

Table 3 shows the means and standard deviations of the ethnic stereotyped attitudes of Albanian students towards different ethnic groups. The minimum score is 10 and the maximum one is 70 ( 40 is neutral attitude). The closer to 10 , the more positive the stereotyped attitude is towards other religious groups. The closer to 70 , the more negative the stereotyped attitude is towards other religious groups. The data in table 3 shows that students have negative stereotyped attitude toward the Serbs $(M=54.65)$ and Greeks $(M=50.91)$. Stereotyped attitude towards 
PROBLEMS

OF EDUCATION

IN THE $21^{\text {st }}$ CENTURY

Volume 48, 2012

132

other ethnic groups: Montenegrins, Slovenians, Macedonians and Croatians tend to be positive to neutral (means vary from 10 to 40 ). The respondents have more positive stereotyped attitudes toward Croatians.

Table 3. The means of Albanian students ethnic stereotyped attitudes toward other Balkan nations.

\begin{tabular}{|c|c|c|c|c|}
\hline & Minimum & Maximum & Mean & Std. Deviation \\
\hline Serbs & 10.00 & 70.00 & 54.65 & 12.83 \\
\hline Greeks & 10.00 & 70.00 & 50.91 & 19.59 \\
\hline Macedonians & 10.00 & 70.00 & 39.66 & 10.62 \\
\hline Slovenians & 10.00 & 70.00 & 38.38 & 13.10 \\
\hline Montenegrins & 10.00 & 70.00 & 38.16 & 10.24 \\
\hline Bosnian & 10.00 & 70.00 & 38.06 & 9.11 \\
\hline Croatians & 10.00 & 70.00 & 36.23 & 8.29 \\
\hline
\end{tabular}

Table 4 shows the correlation between the social distance and the ethnic stereotypes.

Table 4. Pearson Product-moment Correlations between ethnic distance and ethnic stereotypes.

\begin{tabular}{|c|c|}
\hline & Ethnic stereotypes \\
\hline Ethnic distance towards Greeks & $0.46^{* *}$ \\
\hline Ethnic distance towards Macedonians & $0.29^{* *}$ \\
\hline Ethnic distance towards Montenegrins & $0.28^{* *}$ \\
\hline Ethnic distance towards Serbs & $0.30^{* *}$ \\
\hline Ethnic distance towards Croatians & $0.28^{* *}$ \\
\hline Ethnic distance towards Slovenians & $0.18^{* *}$ \\
\hline${ }^{* *}$. Correlation is significant (0.01; 2-tailed) & \\
\hline
\end{tabular}

It indicates that there is a positive linear correlation between the ethnic distance and the ethnic stereotypes related to each ethnic group. From the statistical point of view, the correlation coefficients vary from weak to moderate.

\section{Discussions}

There is a total lack of secondary data pool to compare the results obtained from the analysis of the data gathered in this research. Previous research is totally missing in the country. Comparison with the research conducted in other Balkan countries seems impossible because of the lack of similarities in sample and methodology. It was made in condition of total lack of any secondary data analysis. Similar to some surveys conducted in the countries of former Yugoslavia (Mihic, Milin \& Logar, 2002; Kandido-Jakšić, 2008; Maleska, 2010; Beska, Majcevska, Kenig, Ballazhi \& Tomovska, 2009; Joveska, 1998), this study reveals that Albanian 
students have negative ethnic stereotypes towards Balkan ethnic groups mainly towards Serbs and Greeks and keep quite distant from them.

The fact why the Albanian students show greater ethnic distance to Serbs is comprehensible provided the historical context of the relations between Serbia and Albania, and to the actual context of relations between Serbia and Kosovo, population of which belongs in the greatest majority to Albanian ethnicity of Kosovo, in comparison to other ethnic groups which have previously been part of the former Yugoslavian Republic (Kandido-Jakšić, 2008).

Similarly, the fact that Albanian students reveal likewise a greater ethnic social distance to Greeks can be explained with the ongoing conflicts in the history of these two countries, which from time to time have aggravated in respect to territorial claims, the present day treatment of the Albanian immigrants in Greece and due to the ethnic stereotypes revealed from Greeks towards them. According to Zheleznova (2003) in a study conducted in 1993, the least favourite ethnic group after the Turks is Albanians. The relations between the two countries have been continuously tense because of negative consideration by media.

The ethnic stereotypes and the social distance with other Balkan ethnic groups are more moderate due to the lack of conflict history with Albania. The findings are in line with the thesis that negative stereotypes intensify when ethnic groups have present conflicts amongst themselves (Bonacich, 1972).

\section{Conclusions}

Albanian students reveal great social distance and intense ethnic stereotypes towards some Balkan ethnic groups. The fact that these findings happened to be amongst the most educated part of the Albanian youth may lead to the assumption that there exist massive ethnic stereotypes amongst the rest of the population, mainly in elderly, less educated population. This calls for more holistic research. Exploration of ethnic stereotypes, prejudices, hostile attitudes will definitely lead to exploring the causes and ways to avoid them. This would lead to better relations and sustainable peace in the Balkans.

\section{References}

Allport, G. (1958). The Nature of Prejudice. Addison-Wesley, Cambridge, MA. (Originally published in 1954).

Beska, P. V., Majcevska, M., Kenig, N., Ballazhi, S., Tomovska, A. (2009). Multiculturalism and inter ethnic relations in education. UNICEF Country Office.

Bogardus, E. S. (1947). Measurement of Personal-Group Relations. Sociometry, 10, 306-311.

Bonacich, E. (1972). A theory of ethnic antagonism: The split labor market. American Sociological Review, 37, 547-292.

Brown, M, E., Cote, R. O, Jr., Lyn-Jones, M. S., Miller, E. S. (1997). Nationalism and Ethnic Conflict. The MIT Press, London.

Burdiak, V. (2010). Influence of ethnic stereotypes on the development of political relations in the Balkans. Codrul Cosminului, 16 (2), 147-157. Retrieved 5. 8. 2012, from http://www/codru_net/ CC16/2/stereotypes.pdf

Cronbach, L. J. (1951). Coefficient alpha and the internal structure of tests. Psychometrika, 16 (3), $297-$ 334.

Devine, P. (1989). Stereotypes and prejudice: Their automatic and controlled components. Journal of Personality and Social Psychology 56, 5-18.

Weber, R., Crocker, J. (1983) Cognitive processes in the revision of stereotypic beliefs. Journal of Personality and Social Psychology, 45, 961-977.

Gilbert, D., Hixon, J. (1989). The trouble of thinking: Activation and application of stereotypic beliefs. Journal of Personality and Social Psychology, 60, 509-517. 
PROBLEMS

OF EDUCATION

IN THE $21^{\text {st }}$ CENTURY

Volume 48,2012

134

Glick, P., Fiske, S. T. (2001). An ambivalent alliance: Hostile and benevolent sexism as complementary justifications for gender inequality. American Psychology, 56, 109-118.

Joveska, J. L. (1998). Social Distance in Adolescents in the Republic of Macedonia. New Balkan Politics. Retrieved from http://www.newbalkanpolitics.org.mk/oldsite/issue2.asp

Kandido-Jakšić, M. (2008). Social distance and attitudes towards ethnically mixed marriages. Psychological, 41 (2), 149-162.

Kandido-Jakšić, M. (1999). Ethnically mixed marriages and social distance towards members of some ex-Yugoslav nations. Sociological, 41, 103-124.

Katz, D., Braly, K. (1935). Racial prejudices and racial stereotypes. Journal of Abnormal and Social Psychology, 30, 175-193.

Kokkali, I. (2007). "Spatial proximity and social distance: Albanian immigration in Thessaloniki, Greece." 3rd LSE PhD Symposium on Modern Greece. Retrieved 12.8.2012, from http://www.lse.ac.uk/ collections/hellenicObservatory/pdf/3rd_Symposium/PAPERS/KOKKALI\%20IFIGENEIA.pdf

Lippman, W. (1922). Public opinion. New York: Harcourt Brace.

Maleska, M. (2010). Interethnic relations in Macedonia: people Centered Analyses. New Balkan Politics, 12, from http://www.newbalkanpolitics.org.mk/documents/pdf/NBP,Maleska\%20M.pdf

Maria Vidali. (1999). Living in a Policy Vacuum: The Plight of Albanian Immigrants in Greece. Central Europe Review, 1 (21). Retrieved 16.9.2012, from http://www.ce-review.org/99/21/vidali21.html

Neofotistos, P.V. (2004). Beyond stereotypes: Violence and Porousness of Ethnic Boundaries in the Republic of Macedonia. History and Anthropology, 15 (1), 47-67.

Opačić, B., Vujadinović, B. (2005). Ethnic distance and ethnic stereotype as factors influencing the decision on repatriation. Retrieved 9.7. 2012, from http://www.ian.org.rs/publikacije/posleratnezajednice/ book/09ETHNIC-DISTANCE.pdf.p.119

Šiber, I. (1997). War and the changes in social distance toward the ethnic minorities in the Republic of Croatia. Politička Misao, 34 (5), 3-26.

Sidanius, J., Pratto, F. (1999). Social Dominance: An Intergroup Theory of Social Hierarchy and Oppression. Cambridge University Press, New York.

Tajfel, H. (1981b). Human Groups and Social Categories. Cambridge University Press, Cambridge, UK.

Tajfel, H., Turner, J. C. (1979). An integrative theory of intergroup conflict. In Austin, W. G., and Worchel, S. (Eds.), The Social Psychology of Intergroup Relations, Brooks-Cole, Monterey, CA.

Tajfel, H. (1981a). Social stereotypes and social groups. In J. C. Turner \& H. Giles (Eds.), Intergroup behavior. Oxford: Blackwell. P.144-167).

Todorova, M. (1997). Imagining the Balkans. Oxford University Press.

Vujadinovic, B., Djukanovic, A., Petkvovic, B. (2003). Youth within the municipalities of Milici, Brutanac and Srebrenica-living conditions, social activities, expectations from the future and interethnic binding. UNDP.

Yamane, T. (1967). Statistics: An introductory analysis, $2^{\text {nd }}$ Ed., New York: Harper and Row.

Zhelyazkova, A. (2003). Albanian Prospects. IMIR, Sofia, pp. 205-207.

Advised by Milika Dhamo, University of Tirana, Albania

Received: October 04, 2012

Accepted: November 22, 2012

\begin{tabular}{|c|c|}
\hline Edmond Rapti & $\begin{array}{l}\text { Associate Professor, Vice Rector of University of Tirana, Place "Mother Tereza" No. } \\
\text { 1, Tirana, Albania. } \\
\text { Phone: +355 } 42222547 . \\
\text { E-mail : edi_rapti@yahoo.com }\end{array}$ \\
\hline Theodhori Karaj & $\begin{array}{l}\text { Professor, Dean of Faculty of Social Sciences, University of Tirana, Milto Tutulani } \\
\text { Street 1, Tirana, Albania. } \\
\text { Phone: + } 35542230369 . \\
\text { E-mail: dhorikaraj@yahoo.com }\end{array}$ \\
\hline
\end{tabular}

